\title{
PLASMA AND CANCEROUS TISSUE CONCENTRATIONS OF Zn, Cu AND Mn IN PATIENTS UNDERGOING SURGICAL TREATMENT FOR GASTROINTESTINAL CANCER
}

\author{
Monika Szewczyk ${ }^{1}$, Kazimierz Pasternak $^{\mathbf{1}}$, \\ Andrzej Andrzejewski², Andrzej Dąbrowski ${ }^{2}$, \\ Grzegorz Wallner ${ }^{2}$ \\ ${ }^{1}$ Chair and Department of Medical Chemistry \\ ${ }^{2} 2^{\text {nd }}$ Chair and Department of General, Gastrointestinal and Oncological \\ Surgery of the Alimentary Tract \\ Medical University of Lublin
}

\begin{abstract}
Gastrointestinal cancers have a complex and multifactorial etiology and their immediate cause remains to be discovered. Elements such as zinc, copper or manganese, which are important components of antioxidant enzymes, may affect malignant processes.

The objective of this study was to determine zinc, copper and manganese concentrations in the blood, cancerous and healthy control tissue of patients operated on for gastrointestinal malignancies as well as to assess the effect of surgical removal of the tumour on the concentration of these elements.

The study included 68 patients who underwent surgery for gastrointestinal cancers. Patients were divided into three groups according to tumour location: group I - oesophageal cancer, group II - gastric cancer and group III - colorectal cancer. Study material consisted of venous blood samples obtained from patients before the surgery and on the seventh day after the surgery; tissue samples were taken during the surgery.

The study has demonstrated that the malignant disease process causes changes in trace element status both in plasma and in cancerous tissues. Copper concentrations were elevated both in patients' plasma and in cancerous tissues, while a decrease was observed in zinc and manganese concentrations in comparison with control tissue. The surgery affected levels of these elements to various degrees corresponding to the location of removed tumour.
\end{abstract}

dr nauk med. Monika Szewczyk, Chair and Department of Medical Chemistry, Medical University of Lublin, Chodźki 4a, 20-093 Lublin, Poland, phone: +48 815357361 
Key words: zinc, copper, manganese, antioxidants, oesophageal cancer, gastric cancer, colorectal cancer, surgical treatment.

\title{
STĘŻENIE Zn, Cu I Mn W OSOCZU I TKANCE NOWOTWOROWEJ PACJENTÓW LECZONYCH OPERACYJNIE Z POWODU NOWOTWORÓW ZŁOŚLIWYCH PRZEWODU POKARMOWEGO
}

\begin{abstract}
Abstrakt
Nowotwory przewodu pokarmowego mają złożoną i wieloczynnikową etiologię, a ich bezpośrednia przyczyna nie jest znana. Pierwiastki, takie jak: cynk, miedź i mangan, moga wpływać na procesy nowotworowe, gdyż są ważnymi elementami składowymi enzymów antyoksydacyjnych.

Celem badań było oznaczenie stężenia cynku, miedzi i manganu we krwi oraz w tkance nowotworowej i kontrolnej pacjentów operowanych z powodu nowotworów przewodu pokarmowego, a także ocena wpływu operacyjnego usunięcia nowotworu na badane stężenia pierwiastków.

Badaniem objęto 68 chorych operowanych z powodu nowotworów złośliwych przewodu pokarmowego. Chorych podzielono na 3 grupy, biorąc pod uwagę umiejscowienie nowotworu: I - rak przełyku, II - rak żołądka, III - rak jelita grubego.

Materiał do badań stanowiła krew żylna pobierana od chorych przed zabiegiem operacyjnym oraz $\mathrm{w}$ 7. dobie po operacji, a także wycinki tkanek pobierane podczas zabiegu operacyjnego.

Badania dowiodły, że proces nowotworowy powoduje zmiany w statusie pierwiastków śladowych zarówno w osoczu, jak i w tkance nowotworowej. Stężenie miedzi w osoczu chorych wzrastało, podobnie jak $\mathrm{i} w$ tkance nowotworowej, natomiast stężenie cynku i manganu malało $\mathrm{w}$ porównaniu $\mathrm{z}$ kontrolą. Zabieg operacyjny wpływał w różnym zakresie na stężenia pierwiastków, co było zależne od umiejscowienia usuwanej zmiany nowotworowej.
\end{abstract}

Słowa kluczowe: cynk, miedź, mangan, antyoksydanty, rak przełyku, rak żołądka, rak jelita grubego, leczenie operacyjne.

\section{INTRODUCTION}

Gastrointestinal cancers have a complex and multifactorial etiology and their immediate cause remains to be discovered. Nowadays, neoplasms are believed to be induced by DNA damage resulting in mutations and abnormalities of cell division. Previous studies have demonstrated that inflammatory states and cancerous processes are associated with the so-called oxidative stress, or imbalance between the generation of reactive oxygen species and antioxidant concentrations as well as the response of defense enzymes (BARTOSZ 2006, ZysKa, KuCHARZEWSKI 2007).

Such chemical elements as for instance zinc, copper or manganese, constitute important components of antioxidant enzymes; they are involved in DNA biosynthesis and stimulate the immune system; consequently, they may affect cancerous processes (PUZANOWSKA-TARASIEWICZ et al. 2009). 
Zinc has anticancer properties; its antiproliferative and proapoptotic effect has been demonstrated in in vitro studies. The antioxidant effect of zinc is also relevant. Zinc ions protect protein sulfhydryl groups against oxidation. Its antioxidant effect is also associated with the induction of metallothioneins, i.e. proteins with the capacity to remove reactive oxygen species (KNYCHALSKa-KARWAN et al. 1999, ZaborowsKa et al. 2005, BARTOSZ 2006). An essential component of $\mathrm{Cu} / \mathrm{Zn}$ superoxide dismutase, zinc is involved in the elimination of free radicals.

Copper may impair DNA synthesis by displacing zinc necessary to the process. Deficiency of this element also affects the elements of antioxidant defense system in a direct as well as indirect manner (OLSZEWSKI et al. 2003, YAMAN et al. 2007, HADI et al. 2010).

Copper is a cofactor in $\mathrm{Cu} / \mathrm{Zn}$ superoxide dismutase (CuZnSOD) crucial to the process of removing free radicals. Low copper concentrations cause decreased activity of CuZnSOD, CAT, GPx, ceruloplasmin and glutathione (BERGER et al. 2001, SkrZYCKI et al. 2008). Copper may be a diagnostic factor in the cancerous process - persistent lack of changes in serum copper concentrations is a good prognostic factor while elevated copper levels may be a sign of the recurrence of malignancy (DoBRowolski et al. 2000, DARADÓ et al. 2005).

A component of superoxide dismutase (Mn-SOD), manganese is involved in the process of eliminating free radicals generated during metabolic changes in cells (Nozoe et al. 2003, Kot, ZARĘBA 2005).

The objective of the study was to determine zinc, copper and manganese concentrations in the blood, cancerous and healthy control tissues of patients operated on for gastrointestinal malignancies as well as to assess the effect of surgical removal of the tumour on the concentration of these elements.

\section{MATERIALS AND METHODS}

The study included 68 patients operated on for gastrointestinal malignancies at the Second General, Gastroenetrology and Digestive Neoplasm Surgery Clinic in the teaching clinical hospital SPSK1 in Lublin.

Control blood samples were collected from 21 healthy people undergoing regular checkups.

The study was approved by the Bioethics Committee at the Medical University in Lublin (decision no. KE-0254/222/2007).

Patients were divided into three groups according to tumour location: group I - oesophageal cancer (10 subjects), group II - gastric cancer (35 subjects) and group III - colorectal cancer (23 subjects). 
Blood samples were collected before the surgery and on the seventh day after the surgery. Two tissue samples were also obtained from each subject during the surgical treatment: one from cancerous tissue and a control sample from a most distant margin of healthy tissue.

Concentrations of zinc $(\mathrm{Zn})$, copper $(\mathrm{Cu})$ and manganese $(\mathrm{Mn})$ were determined in the plasma and in tissue homogenates by the atomic absorption spectroscopy method (AAS) with the use of a Pye-Unicam atomic absorption spectrophotometer.

Samples of plasma or tissue $(0.5 \mathrm{~g})$ were placed in quartz crucibles and dried at $80-90^{\circ} \mathrm{C}$ for twelve hours. Next, they were ashed in a muffle furnace at $450^{\circ} \mathrm{C}$. The ash was dissolved in a $5 \% \mathrm{HCl}$ solution, placed in volumetric flasks and filled up to a defined volume with double-distilled water. Quantifications were made at wavelengths specific to particular elements, i.e. $213.856 \mathrm{~nm}$ for $\mathrm{Zn}$; $324.754 \mathrm{~nm}$ for $\mathrm{Cu}$; $257.610 \mathrm{~nm}$ for $\mathrm{Mn}$. Plasma concentrations of the elements were given in $\mu \mathrm{mol} \mathrm{l^{-1 }}$, and tissue concentrations in $\mu \mathrm{g} \mathrm{g}^{-1}$ protein.

The software package Statistica v. 7.1 was used to perform statistical analysis of the results of the study.

\section{RESULTS AND DISCUSSION}

Plasma copper concentrations in the subjects ranged between 7.66 and $11.53 \mu \mathrm{mol} \mathrm{l}^{-1}$ and they were statistically lower than in the control group $\left(15.40 \mu \mathrm{mol} \mathrm{l}^{-1}\right.$ ) both prior to and after the surgery. Zinc concentrations before the surgery were similar to those on the seventh day after the surgery; statistically significant differences were observed in groups II and III (Table 1). Moreover, statistically significant differences $(p<0.05)$ were observed in zinc concentrations in all the three groups of patients in relation to the tumour location.

Similar results have been obtained in the study by DRozDA et al. (2008), where characteristically lower zinc concentrations were detected in the plasma of patients suffering from sigmoid colon cancer or rectal cancer compared with the control group.

$\mathrm{Zn}$ concentrations in cancerous tissues ranged between 1.39 and $2.79 \mathrm{ug} \mathrm{g}^{-1}$ protein and were lower than in control tissues (1.43-3.22 $\mathrm{\mu g} \mathrm{g}^{-1}$ protein). No appreciable differences were observed in cases of oesophageal cancer, while $\mathrm{Zn}$ levels in cancerous tissues were lower than in control tissues in colorectal cancer in a statistically significant way (Table 2). This confirms the results obtained by REDDY et al. (2000, 2003) for gastric and kidney malignancies. Lower zinc concentrations in laryngeal cancer were also detected by NiEDZIELSKA et al. (2000). 
Table 1

Plasma Zn concentration in patients undregoing surgery for oesophageal (group I), gastric (II) and colorectal cancer (III)

\begin{tabular}{|c|c|c|c|c|c|c|c|}
\hline \multirow{2}{*}{\multicolumn{2}{|c|}{ Groups }} & \multicolumn{6}{|c|}{ Plasma Zn concentration $\left(\mu \mathrm{mol} \mathrm{l}^{-1}\right)$} \\
\hline & & \multirow{2}{*}{$\begin{array}{c}\bar{x} \\
7.93\end{array}$} & \multirow{2}{*}{$\begin{array}{l}\text { SD } \\
1.39\end{array}$} & \multirow{2}{*}{$\begin{array}{c}\begin{array}{c}\text { range } \\
\text { of variability }\end{array} \\
6.10-10.0\end{array}$} & \multirow{2}{*}{$\frac{S_{1}}{0.001}$} & \multirow{2}{*}{$\begin{array}{c}\mathrm{S}_{2} \\
0.647\end{array}$} & $\mathrm{~S}_{3}$ \\
\hline \multirow{3}{*}{ Before } & I & & & & & & \multirow{3}{*}{0.000} \\
\hline & II & 10.23 & 0.71 & $9.20-11.50$ & 0.000 & 0.000 & \\
\hline & III & 11.53 & 0.95 & $10.10-13.10$ & 0.008 & 0.008 & \\
\hline \multirow{3}{*}{$\begin{array}{l}7 \text { day } \\
\text { after }\end{array}$} & I & 7.66 & 0.84 & $6.90-9.20$ & 0.001 & 0.647 & \multirow{3}{*}{0.000} \\
\hline & II & 11.53 & 1.18 & $10.00-13.80$ & 0.003 & 0.000 & \\
\hline & III & 10.23 & 1.45 & $7.70-12.30$ & 0.002 & 0.008 & \\
\hline \multicolumn{2}{|c|}{$\mathrm{K}$} & 15.40 & 3.80 & $6.80-19.10$ & & & \\
\hline
\end{tabular}

$\mathrm{S}_{1}$ - level of statistical significance when comparing $\mathrm{Zn}$ concentration in groups (I, II, III) with the control group;

$\mathrm{S}_{2}$ - level of statistical significance when comparing plasma $\mathrm{Zn}$ concentration in groups (I, II, III) before the surgery and on the 7th day after the surgery;

$\mathrm{S}_{3}$ - level of statistical significance plasma $\mathrm{Zn}$ concentration of patients in relation to tumour location.

Table 2

Mean $\mathrm{Zn}$ concentration in tissues of patients undregoing surgery for oesophageal (group I), gastric (II) and colorectal cancer (III)

\begin{tabular}{|c|c|c|c|c|c|c|}
\hline \multirow{2}{*}{\multicolumn{2}{|c|}{ Groups }} & \multicolumn{5}{|c|}{$\mathrm{Zn}$ concentration in cancerous tissue ( $\mu_{\mathrm{g} \mathrm{g}} \mathrm{g}^{-1}$ protein) } \\
\hline & & \multirow{2}{*}{$\begin{array}{c}\bar{x} \\
1.39\end{array}$} & \multirow{2}{*}{$\frac{\text { SD }}{0.27}$} & \multirow{2}{*}{$\begin{array}{c}\begin{array}{c}\text { range } \\
\text { of variability }\end{array} \\
1.03-1.81\end{array}$} & \multirow{2}{*}{$\begin{array}{c}\mathrm{S}_{1} \\
0.789\end{array}$} & $\mathrm{~S}_{2}$ \\
\hline \multirow{3}{*}{$\begin{array}{c}\text { Cancerous } \\
\text { tissue }\end{array}$} & I & & & & & \multirow{3}{*}{0.024} \\
\hline & II & 2.79 & 1.93 & $1.06-10.10$ & 0.232 & \\
\hline & III & 1.61 & 0.93 & $0.45-3.82$ & 0.001 & \\
\hline \multirow{3}{*}{ Control tissue } & I & 1.43 & 0.56 & $0.77-2.53$ & 0.789 & \\
\hline & II & 2.99 & 1.79 & $0.94-7.36$ & 0.232 & \\
\hline & III & 3.22 & 1.91 & $0.83-8.00$ & 0.001 & \\
\hline
\end{tabular}

$\mathrm{S}_{1}$ - level of statistical significance when comparing $\mathrm{Zn}$ concentration in cancerous and control tissue;

$\mathrm{S}_{2}$ - level of statistical significance of $\mathrm{Zn}$ concentration in cancerous tissue relation to tumour location. 
As a component of $\mathrm{Cu} / \mathrm{Zn}$ superoxide dismutase, zinc is involved in the process of inactivation of reactive oxygen species. Plasma zinc concentrations change when metabolic activity of the body is increased; a decline is observed in malignancies in various locations (NIEDZIELSKA et al. 2000, DROZDA et al. 2008). Low zinc levels both in plasma and in cancerous tissues may be linked to partial depletion of antioxidant barrier in oxidative stress, i.e. cancer.

Plasma copper concentrations in subjects were within the normal range except for group I, in which the average plasma copper concentration before the surgery was markedly lower and amounted to $44.7 \mathrm{umol} \mathrm{l}^{-1}$. Plasma copper concentrations in patients suffering from gastrointestinal cancers were lower (13.7-15.9 $\left.\mu \mathrm{mol} \mathrm{l}^{-1}\right)$ compared with the control group (17.1 $\left.\mathrm{mmol} \mathrm{l}^{-1}\right)$. Plasma copper concentrations $\left(44.7 \mu \mathrm{mol} \mathrm{l^{-1 }}\right)$ were nearly three-fold as high as in the control group only in patients suffering from oesophageal cancer.

A comparison of copper concentrations before and after the surgery demonstrated that there was a statistically significant decrease after surgical treatment of oesophageal cancer. Statistically significant differences between copper concentrations in all the three groups were observed with regard to tumour location (Table 3).

Table 3

Plasma $\mathrm{Cu}$ concentration in patients undregoing surgery for oesophageal (group I), gastric (II) and colorectal cancer (III)

\begin{tabular}{|c|c|c|c|c|c|c|c|}
\hline \multicolumn{2}{|c|}{ Groups } & \multicolumn{6}{c|}{ Plasma Cu concentration $\left(\mu \mathrm{mol} \mathrm{l}^{-1}\right)$} \\
\cline { 3 - 8 } \multicolumn{2}{|c|}{} & $\bar{x}$ & $\mathrm{SD}$ & $\begin{array}{c}\text { range } \\
\text { of variability }\end{array}$ & $\mathrm{S}_{1}$ & $\mathrm{~S}_{2}$ & \multirow{2}{*}{$\mathrm{S}_{3}$} \\
\hline \multirow{3}{*}{ Before } & I & 44.7 & 9.7 & $26.8-57.2$ & 0.000 & 0.000 & \\
\cline { 2 - 8 } & II & 13.8 & 1.3 & $11.8-15.7$ & 0.035 & 0.880 & \multirow{2}{*}{0.000} \\
\cline { 2 - 8 } & III & 15.9 & 0.8 & $14.8-17.3$ & 0.400 & 0.128 & \\
\hline \multirow{3}{*}{ Day } & I & 15.7 & 0.8 & $14.2-16.8$ & 0.328 & 0.000 & \multirow{2}{*}{0.017} \\
\cline { 2 - 8 } & II & 13.7 & 2.2 & $9.9-17.3$ & 0.034 & 0.880 & \\
\cline { 2 - 7 } & III & 15.2 & 1.23 & $13.8-17.3$ & 0.209 & 0.128 & \\
\hline \multicolumn{2}{|c|}{ K } & 17.1 & 4.7 & $10.6-23.5$ & & & \\
\hline
\end{tabular}

$\mathrm{S}_{1}$ - level of statistical significance when comparing $\mathrm{Cu}$ concentration in groups (I, II, III) with the control group;

$\mathrm{S}_{2}$ - level of statistical significance when comparing plasma $\mathrm{Cu}$ concentration in groups (I, II, III) before the surgery and on the 7th day after the surgery;

$\mathrm{S}_{3}$ - level of statistical significance plasma Cu concentration in relation to tumour location

Copper concentrations in cancerous tissues ranged between 10.3 and $36.7 \mu \mathrm{g} \mathrm{g}^{-1}$ protein, and in control tissue between 6.3 and $22.6 \mathrm{\mu g} \mathrm{g}^{-1}$ protein. In the cancerous tissue of the oesophagus, copper levels were twice as 
low as in control tissues, while in the other cancers, tissue copper concentrations were higher. The differences were statistically significant $(p<0.05)$. Statistically significant differences between copper levels were also observed in regard to tumour location (Table 4).

Table 4

Mean $\mathrm{Cu}$ concentration in tissues of patients undregoing surgery for oesophageal (group I), gastric (II) and colorectal cancer (III)

\begin{tabular}{|c|c|c|c|c|c|c|}
\hline \multirow{2}{*}{\multicolumn{2}{|c|}{ Groups }} & \multicolumn{5}{|c|}{$\mathrm{Cu}$ concentration in cancerous tissue $\left(\mu \mathrm{g} \mathrm{g}^{-1}\right.$ protein) } \\
\hline & & \multirow{2}{*}{$\begin{array}{c}\bar{x} \\
11.6\end{array}$} & \multirow{2}{*}{$\begin{array}{l}\text { SD } \\
3.8\end{array}$} & \multirow{2}{*}{$\begin{array}{c}\begin{array}{c}\text { range } \\
\text { of variability }\end{array} \\
6.4-17.1\end{array}$} & \multirow{2}{*}{$\frac{\mathrm{S}_{1}}{0.000}$} & $\mathrm{~S}_{2}$ \\
\hline \multirow{3}{*}{$\begin{array}{l}\text { Cancerous } \\
\text { tissue }\end{array}$} & I & & & & & \multirow{3}{*}{0.000} \\
\hline & II & 36.7 & 16.9 & $8.9-68.3$ & 0.000 & \\
\hline & III & 10.3 & 3.0 & $4.2-15.4$ & 0.001 & \\
\hline \multirow{3}{*}{ Control tissue } & I & 22.6 & 7.3 & $10.4-39.8$ & 0.000 & \\
\hline & II & 21.8 & 7.4 & $7.5-37.4$ & 0.000 & \\
\hline & III & 6.3 & 1.8 & $3.1-11.2$ & 0.001 & \\
\hline
\end{tabular}

$\mathrm{S}_{1}$ - level of statistical significance when comparing $\mathrm{Cu}$ concentration in cancerous and control tissue;

$\mathrm{S}_{2}$ - level of statistical significance $\mathrm{Cu}$ concentration in cancerous tissue in relation to tumour location.

The study carried out by WitKowski et al. (1993) and NiedzieLSKA et al. $(2000,2004)$ has also demonstrated that copper concentrations were lowered in the cancerous tissue of the larynx and oesophageal. However, the study conducted by DARADó et al. (2005) has shown that copper levels were higher in cancerous tissues than in healthy tissues in the large bowel and, as observed by YAMAN et al. (2007), also in the stomach.

Low plasma copper concentrations and high tissue copper concentrations may be associated with the repositioning of copper from blood to tissues as a result of malignant processes. Elevated plasma copper concentrations correlating with its low concentrations in cancerous tissues in oesophageal cancer remain to be explained.

Plasma manganese concentrations in subjects suffering from cancer ranged between 1.27 and $1.81 \mu \mathrm{mol} \mathrm{l} \mathrm{l}^{-1}$ and were lower than its concentrations in the control group $\left(3.03 \mu \mathrm{mol} \mathrm{l} \mathrm{l}^{-1}\right)$, which was statistically significant.

Mn levels before the surgery did not significantly differ from its levels on the seventh day after the surgical treatment, but there was a statistically significant $(p<0.05)$ increase in manganese concentrations on the seventh day after the surgery in comparison to its values before the surgery in group II. Moreover, statistically significant differences in manganese levels prior to the surgery between groups I, II and III were observed (Table 5). 
Plasma Mn concentration in patients undregoing surgery for oesophageal (group I), gastric (II) and colorectal cancer (III)

\begin{tabular}{|c|c|c|c|c|c|c|c|}
\hline \multirow{2}{*}{\multicolumn{2}{|c|}{ Groups }} & \multicolumn{6}{|c|}{ Plasma Mn concentration $\left(\mu \mathrm{mol} \mathrm{l}^{-1}\right)$} \\
\hline & & \multirow{2}{*}{$\begin{array}{c}\bar{x} \\
1.64\end{array}$} & \multirow{2}{*}{$\begin{array}{l}\text { SD } \\
0.51\end{array}$} & \multirow{2}{*}{$\begin{array}{c}\begin{array}{c}\text { range } \\
\text { of variability }\end{array} \\
0.90-2.20\end{array}$} & \multirow{2}{*}{$\begin{array}{c}\mathrm{S}_{1} \\
0.000\end{array}$} & \multirow{2}{*}{$\begin{array}{c}\mathrm{S}_{2} \\
0.538\end{array}$} & $\mathrm{~S}_{3}$ \\
\hline \multirow{3}{*}{ Before } & I & & & & & & \multirow{3}{*}{0.042} \\
\hline & II & 1.27 & 0.33 & $0.80-1.80$ & 0.000 & 0.001 & \\
\hline & III & 1.50 & 0.33 & $0.90-1.80$ & 0.000 & 0.928 & \\
\hline \multirow{3}{*}{$\begin{array}{l}7 \text { day } \\
\text { after }\end{array}$} & I & 1.50 & 0.34 & $0.90-1.80$ & 0.000 & 0.538 & \multirow{3}{*}{0.110} \\
\hline & II & 1.81 & 0.57 & $0.90-2.70$ & 0.000 & 0.001 & \\
\hline & III & 1.51 & 0.34 & $0.90-1.80$ & 0.000 & 0.928 & \\
\hline \multicolumn{2}{|c|}{$\mathrm{K}$} & 3.03 & 3.30 & $2.50-3.50$ & & & \\
\hline
\end{tabular}

$\mathrm{S}_{1}$ - level of statistical significance when comparing $\mathrm{Mn}$ concentration in groups (I, II, III) with the control group;

$\mathrm{S}_{2}$ - level of statistical significance when comparing plasma Mn concentration in groups (I, II, III) before the surgery and on the $7^{\text {th }}$ day after the surgery;

$\mathrm{S}_{3}$ - level of statistical significance plasma Mn concentration in relation to tumour location.

Manganese concentrations in cancerous tissues ranged between 0.23 and $1.72 \mu \mathrm{g} \mathrm{g}^{-1}$ protein and were similar to its concentrations in control tissues (0.30-1.33 $\left.\mathrm{ug} \mathrm{g}^{-1}\right)$. Statistically significant differences were observed only in manganese concentrations in cancerous tissues depending on the location of cancer (Table 6).

Table 6

Mean Mn concentration in tissues of patients undregoing surgery for oesophageal (group I), gastric (II) and colorectal cancer (III)

\begin{tabular}{|c|c|c|c|c|c|c|}
\hline \multirow{2}{*}{\multicolumn{2}{|c|}{ Groups }} & \multicolumn{5}{|c|}{ Mn concentration in cancerous tissue $\left(\mu \mathrm{g} \mathrm{g}^{-1}\right.$ protein $)$} \\
\hline & & \multirow{2}{*}{$\begin{array}{c}\bar{x} \\
0.23\end{array}$} & \multirow{2}{*}{$\frac{\text { SD }}{0.08}$} & \multirow{2}{*}{$\begin{array}{c}\begin{array}{c}\text { range } \\
\text { of variability }\end{array} \\
0.15-0.36\end{array}$} & \multirow{2}{*}{$\frac{\mathrm{S}_{1}}{0.201}$} & $\mathrm{~S}_{0}$ \\
\hline \multirow{3}{*}{$\begin{array}{l}\text { Cancerous } \\
\text { tissue }\end{array}$} & I & & & & & \multirow{3}{*}{0.000} \\
\hline & II & 0.89 & 0.65 & $0.33-3.33$ & 0.210 & \\
\hline & III & 1.72 & 0.72 & $0.65-3.25$ & 0.066 & \\
\hline \multirow{3}{*}{ Control tissue } & I & 0.30 & 0.14 & $0.16-0.58$ & 0.201 & \\
\hline & II & 1.06 & 0.94 & $0.29-4.50$ & 0.210 & \\
\hline & III & 1.33 & 0.70 & $0.68-3.46$ & 0.066 & \\
\hline
\end{tabular}

$\mathrm{S}_{1}$ - level of statistical significance when comparing Mn concentration in cancerous and control tissue;

$\mathrm{S}_{2}$ - level of statistical significance $\mathrm{Mn}$ concentration in cancerous tissue in relation to tumour location. 
As a component of superoxide dismutase (MnSOD), manganese is involved in the process of eliminating free radicals generated in metabolic changes. Its low plasma levels may be linked to low MnSOD activity in the course of malignant disease processes caused by intense oxidative stress and overproduction of free radicals.

\section{CONCLUSIONS}

1. Malignant disease processes cause changes in trace element status both in plasma and in cancerous tissue.

2. Copper concentrations are elevated in plasma and in cancerous tissue of the patients, while zinc and manganese concentrations are low compared with the control group.

3. Surgery affects concentrations of the elements to various degrees, depending on the location of removed cancer (oesophageal cancer, gastric cancer, colorectal cancer).

\section{REFERENCES}

Bartosz G. 2006. Another face of oxygen. Free radicals in nature. PWN, Warszawa. (in Polish)

Berger M., Baines M., Chiolero R.L., Wardle C.A., Cayeux Ch., Shenkin A. 2001. Influence of early trace element and vitamin $E$ supplements on antioxidant status after major trauma: a controlled trial. Nutr. Res., 21: 41-54.

Daradó A., Rzetecki T., Dziki A., Sapota A. 2005. Biological levels of cadmium, zinc, copper and selenium in patients with colorectal cancer. Bromatol. Chem. Toksykol., 4 (38): 371-376. (in Polish)

Dobrowolski Z., Drewniak T., Cichocki T., Kwiatek W. 2000. Concentrations of copper and zinc and the $\mathrm{Cu} / \mathrm{Zn}$ ratio in blood plasma and tissue of clear ell carcinoma of the kidney. Urol. Pol., 53(1): 51-63. (in Polish)

Drozda R., Trzciński R., Rutkowski M., Grzegorczyk K., Dziki Ł., Sygut A., Koєomecki K., Dziki A. 2008. Concentrations of anti-oxidant trace elements - selenium and zinc - in patients with the cancer of the sigmoid colon or rectum. Gastroenterol. Pol., 15(6): 391-395. (in Polish)

Hadi S.M., Ullah M.F., Shamim U., Bhatt S.H, Azmi A.S. 2010. Catalytic therapy of cancer by ascorbic acid involves redox cycling of exogenous/endogenous copper ions and generation of reactive oxygen species. Chemotherapy, 56(4): 280-284.

Knychalska-Karwan Z., Panaś M., Krawczyk K. 1999. Presence of trace elements in carcinous tissue. Mag. Stomatol., 9(7): 17-19. (in Polish)

Кот A., ZARĘBA S. 2005. Produkty zbożowe źródtem żelaza $i$ manganu [Cereal products as a source of iron and manganese]. Rocz. Państ. Zakł. Hig., 56 (1): 91-96 (in Polish.

Niedzielska G., Caruk K., Pasternak K., Szczepański P 2004. Trace elements in inflammatory processes in the larynx]. J. Elementol., 9(4): 639-645. (in Polish)

Niedzielska G., Caruk K., Pasternak K. 2000. Trace elements in tissues of a larynxs attacked by a neoplastic disease. Otolaryngol. Pol., 54 (Suppl. 31): 200-202. (in Polish) 
Nozoe T., Honda M., Inutsuka S., Yasuda M., Korenaga D. 2003. Significance of immunohistochemical expression of manganese superoxide dismutase as a marker of malignant potential in colorectal carcinoma. Oncol. Rep., 10(1): 39-43.

Olszewski J., Latusiński J., Kita A. 2003. A comparative evaluation of concentrations of antioxidant elements in blood plamsa and tissue bioptates in patients with papilloma or carcinoma of the larynx. Otolaryngologia, 2(2): 90-93. (in Polish)

Puzanowska-Tarasiewicz H., Ku•micka L., Tarasiewicz M. 2009. Biological functions of selected elements. Pol. Merk. Lek., 27(161): 419-422. (in Polish)

Reddy S.B., Charles A.J., Raju G.J., Vijayan V., Reddy B.S., Kumar M.R., Sundareswar B. 2003. Trace elemental analysis of carcinoma kidney and stomach by PIXE method. Nucl. Instr. Meth. Phys. Res. B., 207: 345-355.

Reddy S.B., Hirose Y., Cohen L.A., Simi B., Cooma I., Rao C.V. 2000. Preventive potential of wheat bran fractions against experimental colon carcinogenesis: implications for human coclon cancer prevention. Cancer Res., 60: 4792-4797.

Skrzycki M., Ścibior D., Podsiad M., Czeczot H. 2008. Activity and protein level of CuZnSOD and MnSOD in benign and malignant liver tumors. Clin. Biochem., 41 (1-2): 91-96.

Witkowski K., KozŁowski A., Pardela M., Piecuch J., Walichiewicz P. 1993. The level of copper in plasma and tissues of patients with carcinoma of the esophagus and carcinoma of the large intestine. Wiad. Lek., 46(15-16): 586-588. (in Polish)

Yaman M., Kaya G., Yekeler H. 2007. Distribution of trace metal concentrations in paired cancerous and non-cancerous human stomach tissues. World J. Gastroenterol, 13(4): $612-618$.

Zaborowska M., Wyszkowska Kucharski J. 2005. Role of zinc in plant and animal organisms. J. Elementol., 10(3): 653-664. (in Polish)

Zyska A., Kucharzewski M. 2007. Effect of a diet on concentrations of iron, zinc, copper and selenium in carcinous tissue of the large intestine and polyps of this organ. Ann. Acad. Med. Siles., 61(4): 309-312. (in Polish) 